\title{
A special dish from traditional Turkish Cuisine: Stuffed lamb ribs
}

\author{
Emel Memis Kocaman ${ }^{1}$ \\ Nevin Sanlier ${ }^{2}$
}

\begin{abstract}
Turkish people, who have a long historical background, have a rich culture in terms of cuisine. "Dolma" (meal made by stuffing/wrapping) is one of the most important dishes of the Turkish Cuisine. Turks produced very different types of meals made by stuffing or wrapping and by combining herbals, meat and offals products. Stuffed Lamb Ribs (in Turkish; Kaburga Dolmas1 or Sura) is a special dish that is known in many regions of Turkey. Since it is a dish whose preparation is hard and requires virtuosity, it is generally cooked as a feast meal on religious holidays, and commonly cooked on the Feast of Sacrifice for Muslims. This study aims to present how "Stuffed Lamb Ribs" are prepared, which is one of the traditional dishes of Turkish Cuisine and is one stuffed dish that has started to become forgotten. In this study, the data was collected by personal interviews with source people who are over 60 years old, live in different provinces of Turkey, and traditionally cook this dish. This study ensures the promotion of a very special taste, which has begun to be forgotten and is not known widely even in Turkey, at an international level.
\end{abstract}

Keywords: food; meat; dolma; religion; Turkish Cuisine

\section{Introduction}

Culture is a way of life and all morals and material values of a society as well as the combination of creativity, innovation and traditions. However, it varies from society to society, and from region to region (Şanller and Arrkan 2001: 167-168). Diet culture is directly related to life style of a society. A change in life style leads to change in diet culture. As a matter of fact, cuisine is an indicator of civilization and indispensable elements of a culture (Şanlıer 2004: 227).

Food is not only used for nutrition, but it is also used for referring to one of the most important roles of existence. The unique combined nature of nutrition makes eating a divine and important symbol. This can be clearly seen in the relationships between groups and God, and relations of community members by sharing and exchanging food (Goode 2005).

\footnotetext{
${ }^{1}$ Assistant Professor., Gaziosmanpaşa University, Zile Dinçerler Tourism and Hotel Management College, Department of Food \& Beverage Management, emel.memis@gop.edu.tr

2 Professor, Gazi University, Faculty of Health Sciences, Department of Nutrition \& Dietetics, ntekgul@gazi.edu.tr
} 
Memis Kocaman, E., \& Sanlier, N. (2015). A special dish from traditional Turkish Cuisine: Stuffed lamb ribs. International Journal of Human Sciences, 12(2), 1230-1238. doi:10.14687/ijhs.v12i2.3425

The history of the dolma (meal made by stuffing), which is one of the most important dishes of the Turkish Cuisine and hard to prepare, goes back to the Central Asian Turks (Memiş and Ersoy 2008: 880). The words "dolma (meal made by stuffing)" and "sarma (meal made by wrapping)" are Turkish words; and the fact that these words are seen in Greek, Georgian, Azerbaijani, Armenian, Persian, Arabic, Bulgarian, Macedonian, Hungarian, Romanian, Serbian, Croatian, and Bosnian shows that Turkish Cuisine spread to the neighboring countries (Bayraktar 2012, Giritlioğlu and Avcıkurt 2013).

Dolma (meal made by stuffing/wrapping) is made by stuffing or wrapping carved vegetables, leaves mainly grape leaves and sometimes meat or offals with "dolma içi (ingredients to be stuffed)" which are prepared by adding ingredients such as onions, minced meat, parsley, mint, spices, currant, pine kernel and almonds to rice or cracked wheat. A rich cuisine is created by preparing various meals, which are made by stuffing or wrapping, and depending on the variety of food used as the ingredients, the main ingredient to be stuffed or wrapped, and the wrapping differences (Kocaman 2012: 79-80). Turks migrated from Central Asia to Anatolia and produced very different types of meals made by stuffing or wrapping and by combining herbal products which created lots of diversity in Anatolia within their own culture (Table 1).

Table 1: Types of dolma (meal made by stuffing) in Turkish Cuisine (Baysal et al. 2005: 85, Kocaman 2012: 79-80)

\begin{tabular}{|c|c|c|}
\hline Stuffed Vegetables & Stuffed Leaves & Stuffed Meat and Offals \\
\hline $\begin{array}{l}\text { Stuffed Groom (stuffed zucchini) } \\
\text { Sour Stuffed Winter (stuffed dried } \\
\text { eggplant and red pimento) } \\
\text { Peppers stuffed with minced meat } \\
\text { Tomatoes stuffed with minced meat } \\
\text { Squash stuffed with minced meat } \\
\text { Celery stuffed with minced meat } \\
\text { Eggplant stuffed with minced meat } \\
\text { Leek stuffed with minced meat } \\
\text { Onion stuffed with minced meat } \\
\text { Turnip stuffed with minced meat } \\
\text { Eggplant stuffed with chickpeas } \\
\text { Quince stuffed with molasses } \\
\text { Quince stuffed with sugar Stuffed } \\
\text { squash blossoms } \\
\text { Pepper stuffed with olive oil } \\
\text { Celery stuffed with olive oil } \\
\text { Eggplant stuffed with olive oil } \\
\text { Artichoke stuffed with olive oil }\end{array}$ & $\begin{array}{l}\text { The ones made with grape leaves } \\
\text { Grape leaf stuffed with olive oil } \\
\text { Grape leaf stuffed with minced } \\
\text { meat } \\
\text { Grape leaf stuffed with broad } \\
\text { beans } \\
\text { Grape leaf stuffed with lentil } \\
\text { Weak meal made by stuffing } \\
\text { plums } \\
\text { Grape leaf stuffed with cracklings } \\
\text { Grape leaf stuffed with buffalo } \\
\text { The ones made with other leaf } \\
\text { vegetables } \\
\text { Cabbage wrapped by minced } \\
\text { meat } \\
\text { Cabbage wrapped by lentil } \\
\text { Cabbage wrapped by olive oil } \\
\text { Meal made by wrapping cherry } \\
\text { leaf } \\
\text { Meal made by wrapping mulberry } \\
\text { leaf } \\
\text { Meal made by wrapping leaf beet } \\
\text { Meal made by wrapping black } \\
\text { cabbage }\end{array}$ & $\begin{array}{l}\text { Stuffed Lamb Ribs } \\
\text { Stuffed Chickens } \\
\text { Stuffed Turkey } \\
\text { Tripe of Mutton Stuffed with } \\
\text { Rice and Liver } \\
\text { Stuffed Mutton Intestines } \\
\text { Stuffed Goose } \\
\text { Stuffed Partridge } \\
\text { Stuffed Ouzel } \\
\text { Stuffed Crane } \\
\text { Stuffed Suet }\end{array}$ \\
\hline
\end{tabular}


In the Ottoman Empire era, sultans and queens had various dishes prepared in order to let statesmen and foreign guests eat and develope new recipes. There was a lot of interaction with the different cuisines of every culture that was conquered in the rising period of the Ottomans. Therefore, rich and delicious dishes displaying the creativity and skills of Turkish women and cooks were formed (Sürücüoğlu and Akman 1998).

Accordingly, this study was made to promote stuffed lamb ribs worldwide, which is specific to Turkish Cuisine and has begun to be forgotten, and a dish that must be promoted.

\section{Methodology}

This study aims to present the preparation method, features, cultural importance, energy and nutritional values of Stuffed Lamb Ribs (in Turkish; it is named Sura in the southern and west regions, Kaburga Dolmast in the other regions in Turkey), which is one of traditional dishes of Turkish Cuisine. The study was undertaken in eight districts and provinces of Turkey, there Stuffed Lamb Ribs are cooked such as Kızılcahamam/Ankara, Gazipaşa/Antalya, Burhaniye/Balıkesir, Diyarbakır, Gaziantep, Alaşehir/Manisa, Mersin, Şanlıurfa. Data was collected by personal interviews with women over 60 years old, field visits and observation. A questionnaires which included open ended questions was used to derive detailed information. Individuals that were born and are living in provinces where stuffed lamb ribs are still cooked were included in the study in order to determine traditional cooking methods, features and cultural importance. Thus, details specific to different regions of 'Turkey were attempted to be determined. Moreover, the subject was examined completely by taking advantage of related literature. In the study, the preparation stages of stuffed lamb ribs were presented with photographs. The energy and nutrient composition of the Stuffed Lamb Ribs were calculated using the Nutrition Information System (BeBiS) program (BEBIS 2004).

\section{Results and discussion}

\section{Preparation of stuffed lamb ribs}

Stuffed Lamb Ribs are a traditional and rarely known dish of Turkey. Generally taking ribs of a lamb or goat together with a forearm as a whole, and then opening a gap between bone and meat, stuffing ingredients, and then cooking in the oven to prepare the dish. Generally lamb is preferred when making the dish, and goat isn't preferred as often; but if goat is used, a kid is preferred (Ecmel 2009). The preparation stages of stuffed lamb ribs are explained as follows: 
1. The right rib of a one-year old lamb is bought together with their forearm.

2. A gap between bone and meat wherein ingredients will be stuffed is opened manually (Figure 1 and 2).

3. The surface of the meat and opened gap are cured.

4. Half-baked rice, chopped liver, parsley, salt, and black pepper are mixed and, ingredients to be stuffed are prepared.

5. Ingredients are stuffed in the gap opened in the rib (Figure 3 and 4).

6. The gap is stitched (Figure 5).

7. Diluted tomato paste is coated on the surface of meat (In some regions, yoghurt is also coated).

8. It is placed in a deep tray and the tray is filled with water (Figure 6).

9. It is cooked in a stone oven for 8 to 9 hours (Figure 7).

Note: After the oven is heated completely after the wood has started to burn, the ashes are cleaned, and then the trays are cleaned, where the stuffed lamb ribs are placed. Additionally, casseroles filled with water are placed in the oven to increase the humidity of the oven (Atli 2014, Giray 2014 and Memiş 2014).

Stuffed lamb ribs are commonly known in the west, south and southeast regions of Turkey. In the provinces of the south and east of Turkey, the ingredients that are used as stuffing, also known as "iç pilav" in Turkish Cuisine, are prepared by adding seasonings such as currant, basil, parsley, tallow, meat cubes, black pepper, pimento, kernels of almonds, and pine kernel are the ingredients usually used as stuffing. The ingredients used as stuffing vary according to the regions as well as people, and the aforementioned ingredients are not standard. Also, the cooking method is different in the south and east of Turkey. Stuffed lamb ribs is first cooked on the stove in steam for 2 to 3 hours and then baked for 10 to 30 minutes; then the cooking is completed (Ecmel 2009, TPE 2009, Baydur 2014, Bekmezci 2014, Tuğlu 2014). In some provinces (i.e. Mersin and Kizllcahamam/Ankara), the ingredients to be used as stuffing are prepared with rice, minced meat, onions, salt, and black pepper, and then cooked in steam (Güçlü 2014, Tekgül 2014). In some regions (for example; Gazipaşa/Antalya), ribs are boiled before stuffing them, then the ingredients are stuffed, and then finally the ribs are baked at the last stage (Aslan 2014, Gümüş 2014). In the west regions (for example; Alaşehir/Manisa, Burhaniye/Balıkesir), stuffed lamb ribs is cooked in the oven, generally with wood-fired oven (Atlı 2014, Giray 2014, Memiş 2014). In the east regions, the right rib of a one-year old lamb is taken with 9 to 12 ribs and prepared for stuffing; and an almond is an essential part of the ingredients (TPE 2009). 
Memis Kocaman, E., \& Sanlier, N. (2015). A special dish from traditional Turkish Cuisine: Stuffed lamb ribs. International Journal of Human Sciences, 12(2), 1230-1238. doi:10.14687/ijhs.v12i2.3425
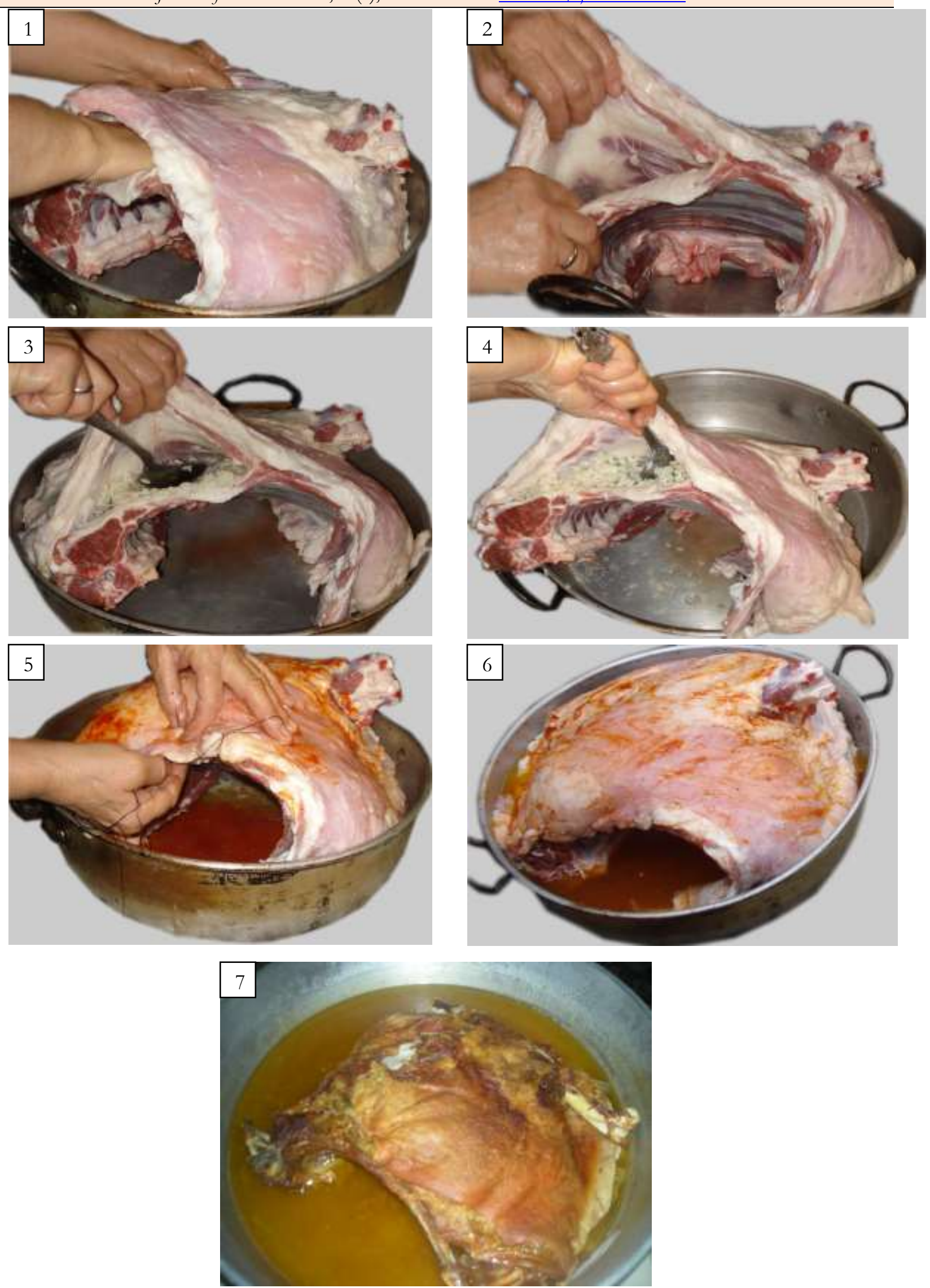

Fig 1-7: 1. Opening a gap in the rib through which ingredients will be stuffed; 2. Gap in the rib through which ingredients will be stuffed; 3 and 4. Stuffing ingredients; 5. Stitching the rib; 6. Ready state of stuffed lamb rib for cooking; 7. Cooked state of stuffed lamb rib 
Memis Kocaman, E., \& Sanlier, N. (2015). A special dish from traditional Turkish Cuisine: Stuffed lamb ribs. International Journal of Human Sciences, 12(2), 1230-1238. doi:10.14687/ijhs.v12i2.3425

\section{Energy and nutrition value of stuffed lamb ribs}

As the main ingredient of stuffed lamb ribs is red meat, it is rich in protein, fat, iron, zinc, and vitamin B. As for rice or cracked wheat, the major ingredients of stuffing, they provide carbohydrates, and the nutritional value of the dish is fulfilled (Baysal and Küçükaslan 2009: 356358, 376-378). Other ingredients are added to be stuffed such as onions, parsley, pine kernel, currant, almonds, liver, and minced meat varies according to the region; and every kind enriches the nutritional value of the dish. The amount of energy and nutrition value of Stuffed Lamb Ribs (for a portion) are shown in Table 2.

Table 2: Energy and nutrition value of stuffed lamb ribs (for a portion)

\begin{tabular}{lc}
\hline Energy and nutrients & Amount \\
\hline Energy (kcal) & 349,0 \\
Protein $(\mathrm{g})$ & 20,6 \\
Fat $(\mathrm{g})$ & 22,4 \\
Cholesterol (mg) & 92,7 \\
Fiber $(\mathrm{g})$ & 1,2 \\
Carbohydrates $(\mathrm{g})$ & 16,4 \\
Calcium $(\mathrm{mg})$ & 40,7 \\
Iron $(\mathrm{mg})$ & 2,9 \\
Magnesium $(\mathrm{mg})$ & 42,6 \\
Phosphorus $(\mathrm{mg})$ & 242,6 \\
Zinc $(\mathrm{mg})$ & 4,8 \\
Sodium $(\mathrm{mg})$ & 439,1 \\
Potassium $(\mathrm{mg})$ & 436,4 \\
Vitamin A ( $\mu \mathrm{g})$ & 1929,9 \\
Vitamin E $(\mathrm{mg})$ & 1,1 \\
Thiamin $(\mathrm{mg})$ & 0,1 \\
Riboflavin $(\mathrm{mg})$ & 0,4 \\
Pyridoxine $(\mathrm{mg})$ & 0,2 \\
Folic acid $(\mu \mathrm{g})$ & 43,9 \\
Vitamin C(mg) & 6,8 \\
\hline
\end{tabular}

\section{Place of stuffed lamb ribs in the Turkish Culture}

Since both the preparation and the serving of stuffed lamb ribs are hard, it is not a frequently cooked meal. It is generally cooked as a feast meal on religious holidays, and commonly cooked on the Feast of Sacrifice for Muslims. According to Islam, the Feast of Sacrifice is a time to pray when Muslims wealthy enough butcher bovine or ovine animals as praying and distribute $1 / 3$ of this meat to poor people. At the same time, the rib of the butchered animal is stuffed at the house of the eldest family member. The tradition leads to a gathering of all of the married children of the family at the family home (Abdülsametoğlu 2014, Baydur 2014, Bekmezci 2014, Memiş 2014).

The dish can also be made during the Ramadan Feast, Hidirellez (celebration of spring and has a religious meaning) (Önal 2008: 1193) and when there are special guests in addition to the Feast of Sacrifice in some regions. In Ramadan, the aim is to understand the situation of poor 
Memis Kocaman, E., \& Sanlier, N. (2015). A special dish from traditional Turkish Cuisine: Stuffed lamb ribs. International Journal of Human Sciences, 12(2), 1230-1238. doi:10.14687/ijhs.v12i2.3425

people by fasting for 30 days and giving a helping hand to them (Abdülsametoğlu 2014, Bekmezci 2014). Furthermore, in some regions of western Turkey, stuffed lamb ribs is made as a tradition for ensuring knitting and conversation between families of engaged couples during their engagement. The family of the fiancé sends a ram on the Feast of Sacrifice and a kid on Hidrellez to the family of the fiancée. The family of the fiancée makes stuffed lamb ribs from it and sends it to the family of the fiancé (Giray 2014, Memiş 2014). In some regions, while the bride is leaving the family home in the wedding, some meals and deserts are sent with stuffed lamb ribs. Stuffed lamb ribs are made for breakfast for the bride and groom for the next morning of the wedding (Eroğlu ve Sarıca 2012, Memiş 2014). These traditions for wedding and engagements are not commonly practiced nowadays.

\section{Conclusions}

The Turkish Cuisine has witnessed a colorful history and different belief systems from the past to the present. Many types of dishes have been forgotten and the culture of Turkish Cuisine has changed because of following reasons: women started to work, faster life styles industrialization and urbanization, the influence of Western culture, preferring finished meals to natural foods, change in kitchen equipment, and fast foods. Since most of the meals cooked in Turkish Cuisine are hard, time consuming, and need virtuosity (Sürücüoğlu and Akman 1998, Maviş 2003: 58-59, Baysal et. al. 2005: 85, Şanlıer 2005).

Cuisine culture maintains its existence in Turkish Folk Culture by changing within its own opportunities and measures. The dishes reflect traditional habits, economic opportunities, regional cooking methods, and human features of the regions; however, some of the important products of Turkish Cuisine have begun to be forgotten. The chances of Turkish culture remaining the same is reduced day by day due to conditions and great changes (Albayrak 1996: 73).

Stuffed lamb rib is generally made by old women nowadays (Günal 2005). Some of the reasons that traditional foods are not cooked any more is due the fact of the difficulty of preparation, changes of life styles, and modern houses do not permit the preparation of traditional meals. This situation causes a concern for stuffed lamb ribs, and recently special restaurants have become famous for stuffed lamb ribs especially in metropolitan cities (Anon 2013). Since the dish is not commonly known in Turkey and the distribution of provinces that knows the special dish extends from the east to the west, to the south of Turkey, the dish is clearly specific to Turkish Cuisine culture. Turkish society is becoming more of a stranger to its 
Memis Kocaman, E., \& Sanlier, N. (2015). A special dish from traditional Turkish Cuisine: Stuffed lamb ribs. International Journal of Human Sciences, 12(2), 1230-1238. doi:10.14687/ijhs.v12i2.3425

own culture, material and moral values, and its cuisine day by day. The disappearance of traditional foods should not be allowed in rapidly changing cuisines, they should be protected and their promotion to society and tourists should be standard (Tekgül and Baykan 1993: 9).

\section{Acknowledgements}

The authors are thankful to traditional knowledge holders, Mrs. Mavi Tekgül, Mrs. Akız Aslan, Mrs. Hamide Gümüş, Mrs. Emine Memiş, Mrs. Nazmiye Giray, Mrs. Belkıze Baydur, Mrs. Hamiyet Bekmezci, Mrs. Ummuhan Atlı, Mrs. Hüsniye Güçlü, Mrs. Fatma Tuğlu who have provided valuable information on the preparation method, features, cultural importance of stuffed lamb ribs.

\section{References}

Albayrak, B. 1996. Mutfağımızı yaşatmaya kararllyız. In V. Milletlerarası Türk. Halk Kültürü Kongresi, 24-29 June, 1996, Ankara, Turkey: Ministry of Culture and Tourism Press, pp. 73-9.

Anon. 2013. Business ads, <http://www.bonubon.com/istanbul/firsat/kaburgaci-selim-amca>; $<$ http://www.ciftefirsat.com/firsat-detay-329-bakirkoy-malatya-sofrasinda-corbak\%C3\%A2git-kebabi-kuzu-tandir-acili-acisiz-zirh-kebabi-kaburga-dolmasi-patlican-tavadomatesli-tava-sebzeli-ta $>$; $\quad<$ http://konyalife.com.tr/haber/mangalyum-sehre-yenilezzetler-katti.html >; <http://tavacirecepusta.com/recep-usta-recep-budak/>.

Bayraktar, Z. 2012. Some findings and evaluations about the role of Turkish Words in Bosnian, Croatian and Serbian Languages on forming the elements of folk culture. Halkbilimi Dergisi (1): 119-27.

Baysal, A. and Küçükaslan, N. 2009. Beslenme ilkeleri ve menü planlaması. Bursa, Turkey: Ekin Yayınevi.

Baysal, A., Merdol, T. K., Ciğerim, N., Sacır, F. H. and Başoğlu, S. 2005. Türk Mutfăğndan örnekler. Ankara, Turkey: Hatipoğlu Basım ve Yayın San.Tic.Ltd.Şti.

BEBIS (Nutrition Information Systems). 2004. Ebispro for Windows, Stutgart, Germany; Turkishversion BeBiS; Data Bases: Bundeslebenmittelschlüssell,11.3 andothersorces.

Ecmel, T. 2009. “Bu yemeği yemediyseniz buyurun”. <http://www.haberform.com/haber/buyemegi-yemediyseniz-buyrun-4817.htm>.

Eroğlu, E. and Sarıca, N. 2012. The wedding traditions of Assyrians in Midyat. Turkish StudiesInternational Periodical For The Languages, Literature and History of Turkish or Turkic 7(3): 1189-99.

Giritlioğlu, İ. and Avcıkurt, C. 2013. Effects of historical structures and cultural richness that the Ottoman Empire bequeathed in the Balkans on the tourism of the region. The Journal of International Social Research 6(28): 113-20.

Goode, J. 2005. Yemek. Fatih Mormenekşe (trans.). Milli Folklor Dergisi 9(67): 172-7.

Günal, V. 2005. The cultural tourism potential of Mardin Province. Marmara Coğrafya Dergisi 11: 91122. 
Memis Kocaman, E., \& Sanlier, N. (2015). A special dish from traditional Turkish Cuisine: Stuffed lamb ribs. International Journal of Human Sciences, 12(2), 1230-1238. doi:10.14687/ijhs.v12i2.3425

Kocaman, E. M. 2012. The usage of grape leaf in Tokat-Zile Kitchen. In III. Traditional Foods Symposium, 10-12 May 2012, Konya, Turkey: Selçuk University Press, pp. 79-81.

Maviş, F. 2003. Endüstriyel yiyecek üretimi. Ankara, Turkey: Detay Yayıncılık.

Memiş, E. and Ersoy, Y. 2008. Traditional food storage methods. In 38. International Congress of Asian and North African Studies (38. ICANAS), 10-15 $5^{\text {th }}$ September, 2007, Material Culture Vol:2, Ankara, Turkey: Supreme Council for Culture, Language and History Press, pp. 885-900.

Önal, M. N. 2008. Muğla'da Hidırellez Bayram1. In 38. International Congress of Asian and North African Studies (38. ICANAS), 10-15 th September, 2007, Literature Problems and Solutions, Ankara, Turkey: Supreme Council for Culture, Language and History Press, pp. 1187-208.

Sürücüoğlu, M. and Akman, M. 1998. Türk Mutfağının tarihsel gelişimi ve bugünkü değişim nedenleri. TSE Standard Ekonomik ve Teknik Dergi 37(439): 42-53.

Şanlıer, N. and Arıkan, B. 2001. Elazı̆̆ Mutfağından unutulmak üzere olan birkaç yemek. In Kamil Toygar (ed) Türk Mutfak Kültürü üzerine araștırmalar. Ankara, Turkey: Türk Halk Kültürü Araştırma ve Tanıtma Vakfi Yay. No:29, pp. 167-75.

Şanlier, N. 2004. “Ankara - Kızılcahamam Mutfağında "Yağlaç”. In Kamil Toygar (ed) Türk Mutfak Kültürü üzerine araștırmalar. Ankara, Turkey: Türk Halk Kültürü Araştırma ve Tanıtma Vakfı Yay. No:11, pp. 227-34.

Şanlier, N. 2005. Opinions of foreign and Turkish tourists on Turkish Cuisine. Gazi University Journal of Gazi Educational Faculty 25(1): 213-27.

Tekgül, N. and Baykan, S. 1993. Evlerimizde pişirilen pilav çeşitleri üzerine bir araştırma. In Kamil Toygar (ed) Türk Mutfak Kültürü üzerine arastırmalar. Ankara, Turkey: Türk Halk Kültürünü Araştırma ve Tanıtma Vakfi Yay. No. 3, pp. 1-11.

Turkish Patent Institute (TPE). 2006. Geographical indication registration certificate. Registration No:123.

\section{Interviewed Persons}

Aslan, Akkız (2014). Personal Interview, Farmer, Date of Birth: 1948, Gazipaşa/Antalya/Turkey.

Atlı, Ummuhan (2014). Personal Interview, Housewife, Date of Birth: 1927, Alaşehir/Manisa/Turkey.

Baydur, Belkıze (2014). Personal Interview, Housewife, Date of Birth: 1955, Diyarbakır/Turkey.

Bekmezci, Hamiyet (2014). Personal Interview, Housewife, Date of Birth: 1955, Gaziantep/Turkey.

Giray, Nazmiye (2014). Personal Interview, Housewife, Date of Birth: 1944, Burhaniye/Balıkesir/Turkey.

Güçlü, Hüsniye (2014). Personal Interview, Housewife, Date of Birth:1942, Mersin/Turkey.

Gümüss, Hamide (2014). Personal Interview, Housewife, Date of Birth: 1925, Gazipaşa/Antalya/Turkey.

Karataş, Hatice. (2014). Personal Interview, Housewife, Date of Birth: 1942, Sivas/Turkey.

Memiş, Emine (2014). Personal Interview, Housewife, Date of Birth: 1955, Burhaniye/Balıkesir/Turkey.

Tekgül, Mavi (2014). Personal Interview, Housewife, Date of Birth: 1942, Kızılcahamam/Ankara/Turkey.

Tuğlu, Fatma (2014). Personal Interview, Housewife, Date of Birth: 1950, Şanllurfa/Turkey. 